\title{
"SANJHYA" THE GODDESS TRADITIONAL ART FORM OF INDIAN ART
}

\author{
Dr. Vikrant Shah 1 (ID) \\ ${ }^{1}$ Assistant Professor (Guest) Government Girls Degree College Ujjain (M.P.), India.
}

Received 1 September 2021

Accepted 13 September2021

Published 30 September2021

\section{CorrespondingAuthor}

Dr. Vikrant Shah,

vikrantshah.sun@gmail.com

DOI

10.29121/granthaalayah.v9.i9.2021. 4227

Funding: This research received no specific grant from any funding agency in the public, commercial, or not-for-profit sectors.

Copyright: (C) 2021 The Author(s). This is an open access article distributed under the terms of the Creative Commons Attribution License, which permits unrestricted use, distribution, and reproduction in any medium, provided the original author and source are credited.

\section{ABSTRACT}

If there is any priority for mankind with bread, cloth and house then it will be said to be an expression of his art, his feelings. This is the reason why pre-historic man has also painted on the walls of caves, which today help historians to understand that ancient civilization is the center of interest of tourists.

"Sanjhya" is a very ancient and the goddess traditional art form of Indian. Perhaps it is a spiritual image to connect the divine to the earth. Apart from Madhya Pradesh, "Sanjhya" is spread in the terrain of Punjab, Rajasthan, Uttar Pradesh, and Haryana etc. Most of the women and youth are making Sanjhya in specific art form. The specialty of these folk art is that these are three-dimensional art on wall consider it to be a reflection of simplicity and culture of ordinary living being through his arts. These artworks show how colorful the imagination of a human can make even a simple straight life. Animals such as peacocks, lions, bears, deer, crocodiles, fish, rivers, mountains, fields, trees, moon are the subjects of their art work, which these community give a multi-colored look on a wall of length and width. These artworks made from unique images of human and divine also. Sanjhya is used on the entrance of the house and on the walls in the courtyard and portrays the family wedding, death or other religious occasions. These pictures are a simple demonstration of the nature and living conditions of these people.

\section{Keywords: Goddess, Art, Traditional, Priority}

\section{INTRODUCTION}

Folk art is an expression of the public design. It started with human civilization and moving with him.

"Sanjhya" the goddess traditional art form of Indian Art. It is a traditional art form, common in many parts of India, mainly in Madhya Pradesh, Punjab, Rajasthan, Uttar Pradesh, and Haryana. This art form is associated with a festival known by the name Sanjhya. The festival of Sanjhya is celebrated by young girls in respect of a goddess named Sanjhya. This festival happens together with the annual worship of ancestral spirits during the Hindu month of Ashwin (September), that lasts a fortnight, beginning with the first day of the dark-half of the Ashwin month and concluding on the sixteenth day i.e., the new moon day of the same month.

During this fortnight, known as pitri-paksha (the fortnight of the ancestors), youthful girls decorate various motifs in an oblong with four gateways, on face walls of their houses. These motifs are stamped in cow-dung every day and are scraped off on next day. In their place new pattern are drawn. This procedure is repeated everyday till the 13th day, when the process of drawing a full blow Sanjhya know as kila kot (A equipped residence) begins. Everyday new design is 
added to the ones drawn on the previous day and finally the symbol depicting the story of Sanjhya is completed on the 14th day. On the new moon day, i.e., the last day of pitri-paksha, kila kot is also scraped off the wall and this along with the earlier scrapings is immersed in the river, accompanied by ritual worship amidst dancing and singing.

The symbol done in bas-relief style with the help of clean cow-dung is adorned with flowers, bright and colorful strips of paper. Every evening, the girls of the same locality gather together to offer prayers to Sanjhya in front of the symbol and sing songs in praise of the goddess. These songs are complete with social and religious suggestions. Though mostly based on various episodes and characters associated with the life of Sanjhya, they are a mirror to the aspirations of young girls and their anxieties over the future married life.

Numerous understandings exist, as to who this Sanjhya is, Sanjhya is daughter of Vishwakarma, the divine architect and wife of the Sun god. She is also the mother of twin Ashwins. Many explanations associated with Sanjhya and its origin. Some of these are as follows.

Sanjhya in forms of Goddess Durga. The mind born daughter of Brahma. Parvati, the wife of Shiva. As replication of the original worship, execute by Parvati to get Shiva as her husband. a drawing of Parvati's childhood form.

The unclear form of vedic deity of dawn, Sanjhya . the name given to the worship performed in honour of the deity of dawn. In the forms of Goddess Radha, the beloved of Krishna. the symbol drawn by Krishna to delight Radha. description of Krishna 's childhood lilas (divine play). a form of Lakshmi-Narayan worship.representative of nava-durgas. a goddess of Braja region.a close and a very dear friend and personal deity of young girls.the wife of the Sun god.

Sanjha is a young woman, who dies a premature and unnatural death. The custom and the symbol are worship of her spirit. At another level Sanjha is a married-out woman, who is not very happy at her in-law's place. She is shown visiting her parents and at the end of her stay, she is taken away by her companion, who is the central target of jokes in these songs.

Whatever may have been the beginning and basis of Sanjhya, in its contemporary and lively form it is a visual and verbal expression of creative and aesthetic response to the world as seen, experienced and desired by the girls who have come of age.

The celebrations of Sanjhya agree with the shraddha ritual performed in honour of dead relatives. Ancestors are propitiated by give food to the Brahmin priests and offering rice and barley balls called pindas to dead relatives. It is believed that ancestors come down on earth during this period to accept these offerings and in return bless their descendents with fertility, prosperity and offspring. "The residence where the traveling souls of the departed relatives take shelter." As to the name Sanjhya "Since the souls enter these abodes in the evening (sanjh), thus the diagrams are called sanjas..... It is equally true that links between ancestoral worship and Sanjhya cannot be denied. It is likely that the origin of Sanjhya ritual lies in the white past, when Sanjhya was probably worshipped as a family deity of the ancestry or relatives. It may be of importance to note here that one of the images of Sanjha the Sanjha that we find on the walls is full of life-force, bright and lively. Sanjhya is celebrated first and foremost as a festival of young girls which works at numerous levels of sense with a wide linguistic field of meanings and symbols.

In the shared Indian tradition, death and rebirth take place parallel. Death and life form a variety. Ancestral respect is closely linked with the concept of continuation of the family. sanjhyas is a shodashi kanya, a sixteen-year aged young 
unmarried., holding within her the seed of formation. The goddess in her virginal form as a sixteen-year-old girl represents source of all life. All the motifs that find place in the Sanjhya pictograph are symbolic of fertility. Her worship during the fortnight dedicated to the dead, who are evoked to give offspring and continuity of life on earth, verbally and visually repeat and revalidates the notion of cosmic rhythm, in which life gets created out of death. The symbol of Sanjhya captures and binds this life-source in a ritually fortified enclosure.

Every sunset, girls jointly offer prayers to Sanjhya. A special plate containing curd, vermillion, rice, grains, incense stick and flowers is used for offering the prayer. A lamp is lighted in front of the symbol and different hymns and songs are sung as mark of offerings to Sanjhya. The food (prasada) offered to deity consists of kular (wheat flour fried in ghee, and mixed with sugar and banana). After the prayers girls often play together and sing Sanjhya songs pleasing Sanjhya join them in their play.

The custom of Sanjhya is slowly evaporateting due to many reasons. There is a marked difference in the way older generation of women reacts to Sanjhya and the way young girls react to it nowadays. Response of the older generation is emotional and inherent in a specific cultural attach. The younger generation is showing signs of indifference to the tradition. The time, when every household in the locality boasted of Sanjhya has gone. The ritual has also outlived its utility. Young girls are more inclined towards pursuing their education and career rather than think about marriage at this tender age. Young mothers also display lack of enthusiasm. Some are even unaware about the beginning of the pitri-paksha and Sanjhya. One of the major reasons for the slow disappearance of Sanjhya is the change in environment. Concrete houses have replaced mud-houses. The relevance of plastering the walls with fresh coat of cow dung and clay mixture is not there anymore. In fact, many people feel that instead of making the walls clean, it spoils the house.

In order to appreciate the complexities and attractiveness of the art one desires to know the myths, rituals, local environment, folk narratives, songs, agricultural patterns, etc. Attempt, therefore should be made to manuscript all these practices to get an absolute picture of the folk art and the psychological build of the artists. Regular art-shows of gifted members of the folk-art society should be organized. These can be made into traveling exhibitions. This will not only become a vehicle for a wider outreach and distribution of the custom to wider community but also help improve the understanding of these art forms and get it the recognition it highly deserves.

\section{REFERENCES}

Bharatiya Kala Evam Sanskriti / Singhania Nitin / Publisher: McGraw Hill Education India Genre / ISBN: 9788194244622,9788194244622

Early Rock Art and Tribal Art in India (An Anthropological Revelation) / somnath chakraborty / PUBLISHER: $\quad$ B.R. PUBLISHING CORPORATION (2018) / ISBN: 9789386223975.

Folk Art of India / Ajit Mookerjee. New Delhi / Publisher : Clarion Books (January 1, 1986) / ISBN-10 : 8185120013 ISBN-13 : 978-8185120010.

Folk and Tribal Designs of India / Enakshi Bhavnani. Bombay : Taraporevala, 1974, / Publisher : Stosius Inc/Advent Books Division (1981) ISBN-10 : 0865900590 ISBN-13 : 978-0865900592.

Indian Art and Culture / Publisher: Mcgrawhill TP / ISBN: 9789385880490, 9385880497 Edition: Second, 2017. 
Indian symbolism : symbols as sources of our customs and beliefs / AUTHOR: RAI GOVINDA CHANDRA WITH A FOREWORD BY R.P.TRIPATHI / PUBLISHER: MUNSHIRAM MANOHARLAL PUBLISHERS PVT. LTD. (1996) / ISBN: 8121500818

Speaking with Pictures Folk Art and the Narrative Tradition in India By Roma Chatterji / Published September 23, 2015 by Routledge India / ISBN 9781138639843. 